\title{
JOURNAL.RU
}

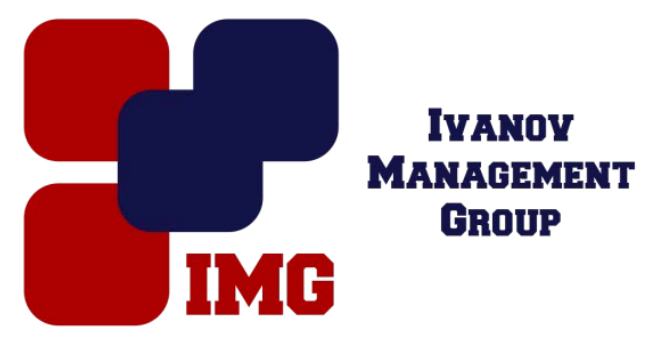

\author{
Хаврошина Ю.О., Захарченко М.Ю., Мельников И.Н., \\ Пичхидзе С.Я., Кайргалиев Д.В.
} Саратовский государственный технический университет им. Гагарина Ю.А.

Саратов, Россия

doi: 10.18411/lj-30-11-2016-4-13

idsp 000001:lj-30-11-2016-4-13

\section{Октадециламин как ингибитор коррозии в огнетушащих составах}

\section{Аннотация}

Рассмотрена возможность использования октадециламина в качестве ингибитора коррозии в огнетушащих составах.

Ключевые слова: октадециламин, коррозия.

Октадециламин стеариновый (Рофамин Т) это химическое соединение, используемое для поверхностной консервации металлов, в энергетике, в химической и других отраслях промышленности. Нами сделано предположение, что определенное количество данного соединения может служить ингибитором коррозии цистерн пожарных автомобилей. Для этого октадециламин растворяли в метаноле и смешивали с огнетушащим составом пожарного автомобиля. В полученный раствор на один месяц помещали образцы углеродистой стали.

Анализ полученных результатов свидетельствует, что использование 0,5 \%-ного раствора октадециламина в огнетушащем составе защищает поверхность металлов от коррозии.

\section{Литература}

1. Хаврошина Ю.О., Белоус Д.С. Разработка огнестойких составов для пропитки огнезащитных костюмов пожарных и спасателей. http://www.school-science.ru/2017/19/26192

2. Белоус Д.С., Ермошин А.Г., Мельников И.Н. Особенности применения антифризов в огнетушащих составах. В сборнике: Юность и Знания Гарантия Успеха - 2016 Сборник научных трудов 3-й Международной молодежной научной конференции. Ответственный редактор Горохов А.А. 2016. С. 315-316. 